\title{
Experimental Study on Solar Cooling Tube Using Thermal/Vacuum Emptying Method
}

\author{
Huizhong Zhao, ${ }^{1,2}$ Haibin Liang, ${ }^{2}$ Wenzhe Sun, ${ }^{1}$ Guoqing Yu, ${ }^{2}$ Dan Cao, ${ }^{1}$ and Jun Ji \\ ${ }^{1}$ Merchant Marine College, Shanghai Maritime University, Shanghai 201306, China \\ ${ }^{2}$ School of Environment and Architecture, University of Shanghai for Science and Technology, Shanghai 200093, China
}

Correspondence should be addressed to Huizhong Zhao, hzzhao@shmtu.edu.cn

Received 1 April 2012; Revised 15 June 2012; Accepted 3 July 2012

Academic Editor: Yu-Pei Huang

Copyright ( 2012 Huizhong Zhao et al. This is an open access article distributed under the Creative Commons Attribution License, which permits unrestricted use, distribution, and reproduction in any medium, provided the original work is properly cited.

\begin{abstract}
A solar cooling tube using thermal/vacuum emptying method was experimentally studied in this paper. The coefficient of performance (COP) of the solar cooling tube was mostly affected by the vacuum degree of the system. In past research, the thermal vacuum method, using an electric oven and iodine-tungsten lamp to heat up the adsorbent bed and $\mathrm{H}_{2} \mathrm{O}$ vapor to expel the air from the solar cooling tube, was used to manufacture solar cooling tubes. This paper presents a novel thermal vacuum combined with vacuum pump method allowing an increased vacuum state for producing solar cooling tubes. The following conclusions are reached: the adsorbent bed temperature of solar cooling tube could reaches up to $233^{\circ} \mathrm{C}$, and this temperature is sufficient to meet desorption demand; the refrigerator power of a single solar cooling tube varies from $1 \mathrm{~W}$ to $12 \mathrm{~W}$; the total supply refrigerating capacity is about $287 \mathrm{~kJ}$; and the COP of this solar cooling tube is about 0.215 .
\end{abstract}

\section{Introduction}

With the improvement of people's living standard, the demand for air conditioner is increasing. Use of CFCs for refrigeration compression has global warming potential (GWP) and ozone depletion potential (ODP), so their use should be minimized. The energy problem has become a major problem facing human development, and has led to efforts to reduce fossil fuel usage. Solar energy, one of the most abundant resources, has many advantages, most importantly that it is environmentally friendly. This has led to attention from the worldwide research community. Adsorption refrigeration uses nature working pairs as refrigerants and solar energy as a heat resource, so it consumes no fossil fuels during refrigeration process and is environmentfriendly.

Ferreira Leite et al. [1] presented the characterization and the pre-dimensioning of an adsorption chiller as part of a $20 \mathrm{~kW}$ air conditioning central unit for cooling a set of rooms that comprises an area of $110 \mathrm{~m}^{2}$. The adsorption chiller's expected coefficient of performance (COP) was found to be around 0.6. Khattab [2] presented the description and operation of a simple structure, low cost solar-powered adsorption refrigeration module. Test results showed that a module using bed technique Type 4 and reflector arrangement Type $\mathrm{C}$ provided the best performance. Wang et al. $[3,4]$ used a compound adsorbent of $\mathrm{CaCl}_{2}$ and activated carbon as working pairs and to produce an ice-making test unit for fishing boats. At evaporating temperatures of $-35^{\circ} \mathrm{C}$ and $-25^{\circ} \mathrm{C}$, the cooling powers are 0.89 and $1.18 \mathrm{~kW}$ respectively. Clausse [5] explored the possibility to perform heating and air-conditioning of a state-of-the-art building located near Paris in France. For air-conditioning, thermal comfort was achieved as indoor temperature was kept below $25^{\circ} \mathrm{C}$ during five consecutive hot days. Anyanwu et al. $[6,7]$ made a solid adsorption refrigerator, achieving a chilled water temperature around $1^{\circ} \mathrm{C}$, suitable for drug, fruits, and vegetables preservation. Khattab $[2,8,9]$ set up a solar-powered adsorption module, this module produced ice $6.9 \mathrm{~kg} / \mathrm{m}^{2}$ and the net solar COP is 0.136 . Guilleminot et al. [10-12] presented experimental study on solar adsorptive ice maker and Heat transfer intensification in the adsorbent bed, and the results show the great improvement in the thermal transfer quality using new consolidated materials. 


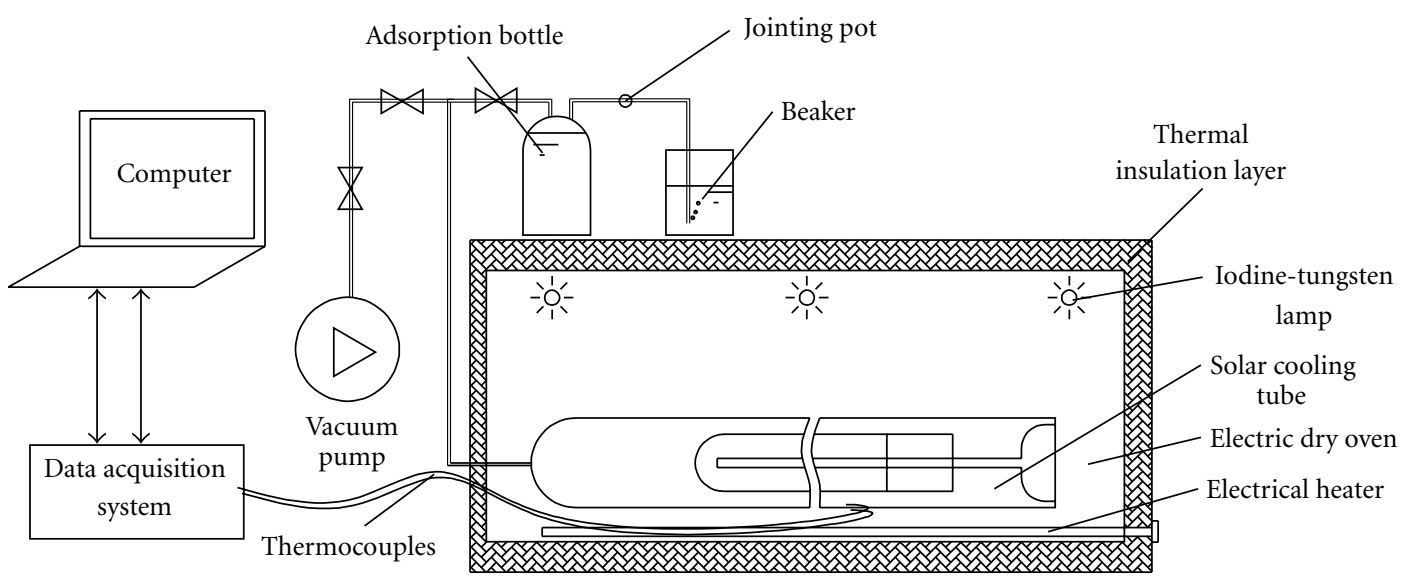

FIGURE 1: Sketch of manufacturing solar cooling tube by means of thermal/vacuum method.

Compared with the above refrigeration system, a solar cooling tube can accomplish the refrigeration cycle in one glass tube. The solar cooling tube [13] and freeze-proof solar cooling tube [14] which uses zeolite/water or active carbon/methanol as working pairs were designed and built. In the past research, the solar cooling tube was manufactured using the thermal vacuum method, which using electric oven and iodine-tungsten lamp to heat up the adsorbent bed, and using $\mathrm{H}_{2} \mathrm{O}$ vapor to expel the air of the solar cooling tube and to reduce air partial pressure. This paper presents a novel thermal vacuum combined with vacuum pump method for producing solar cooling tube, resulting in a highly increased vacuum state.

\section{Manufacture of the Solar Cooling Tube}

The manufacturing process of solar cooling tube is mainly composed of three steps: (1) the preparation filling process; (2) preliminary drying of the solar cooling tube; (3) operating vacuum state by means of thermal/vacuum method. The steps are as follows.

First, the $13 \mathrm{X}$ zeolite is activated in the $325^{\circ} \mathrm{C}$ oven for 8 hours, and then an appropriate amount of highly pure sodium silicate and pure water is added to prepare the adsorption compound. The resulting adsorbent compound has better thermal conductivity and formability than $13 \mathrm{X}$ powder [15]. An electric mixer is used to stir the mixture until it becomes liquid state. A funnel is used to fill the confected the compound adsorbent into all-glass tubular solar collector and preliminary dries it by iodine-tungsten lamp.

Second, put the all-glass tubular solar collector filled with the compound adsorbent into a high borosilicate glass and welding pipe using glass welding lathe, then the semifinished solar cooling tube was made.

Third, $200 \mathrm{~mL}$ pure water is placed into the semi-finished solar cooling tube. The tube is then placed into an electric dry oven, and welding the solar cooling tube with adsorption bottle, jointing pot beaker and vacuum pump. Figure 1 shows a diagram of the system, and Figure 2 is a photograph of the production equipment. After several hours discharging

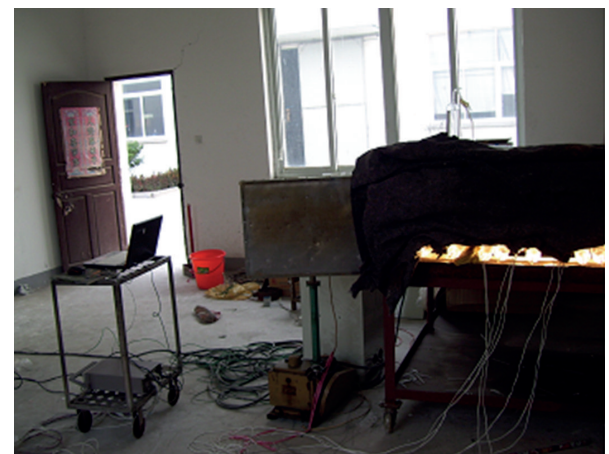

Figure 2: Photograph of manufacturing solar cooling tube.

the air in the solar cooling tube using the thermal emptying method, a vacuum pump is used to evacuate the solar cooling tube. Finally, welding the tail joint completes manufacture of the solar cooling tube.

\section{Principle of Solar Cooling Tube}

The structure of the solar cooling tube is shown in Figure 3. The solar cooling tube contains these major components: solar collector, adsorbent bed, condenser, inner tube, and evaporator. The solar collector, condenser, inner tube, and evaporator are made of hard borosilicate glass. Using $13 \mathrm{X}$ zeolite, the temperature difference between daytime and nighttime corresponds to the adsorption capability difference of refrigerant water; hence, the solar cooling tube achieves refrigeration cycle. The process goes as follows.

During the daytime, the adsorbent bed receives sunlight, and the adsorbent bed temperature rises up to the desorption temperature. When the water vapor flows from adsorbent and raises the water vapor pressure up to the condensing pressure, the desorbed water vapor, which desorbed from adsorbent bed, is condensed in the condenser and flows into the evaporator because of gravity. The water vapor is condensed in the inner wall of the whole outer tube and extracts heat from the environment. In the daytime, the inner 


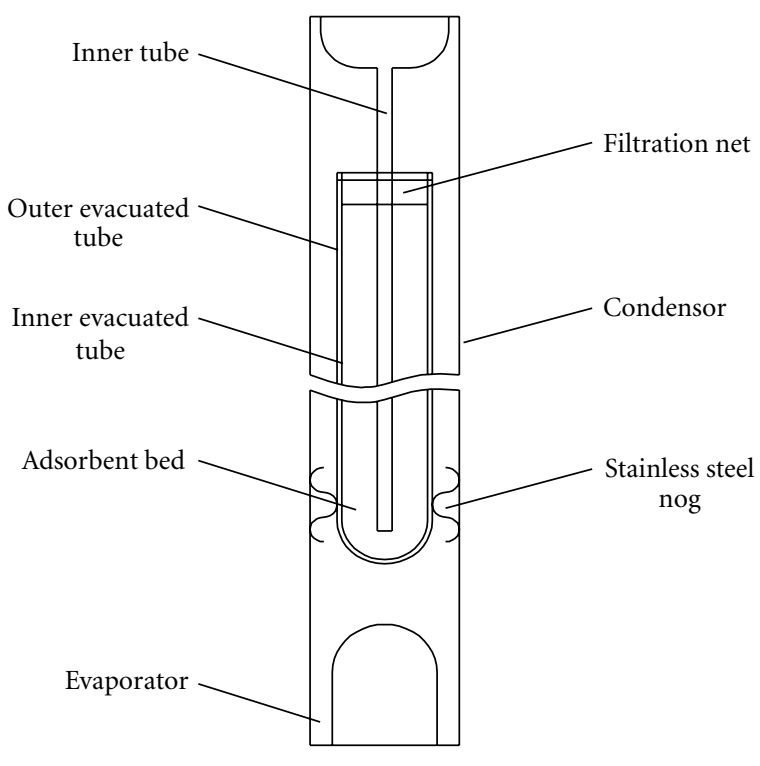

FIGURE 3: Sketch of the solar cooling tube.

tube is full of air and can reduce the thermal loss of adsorbent bed, so the adsorbent bed has higher temperature for desorption. In the whole day, the solar cooling tube receives solar radiation while the water steam continues desorbing from the adsorbent bed and is stored the evaporator. During the nighttime, the adsorbent bed temperature drops after sunset and the inner tube is full with water. This enhances heat transfer for cooling down the adsorbent bed and obtaining heating water. When the adsorbent bed temperature drops to adsorption temperature, the adsorption bed begins to adsorb water vapour and induces a decrease in water vapour pressure, causing the liquid water in the evaporator to vaporize. When the evaporating temperature has lowered enough, the system can provide cooling to the outside. In the adsorption process, the refrigerant water continues to vaporize to supply cooling capacity to the outside; the adsorption refrigeration will continue for the whole night until the next morning.

\section{Experiment Setup}

The sketch and photograph of the experiment in solar cooling tube was shown in Figures 4 and 5. The main apparatus used for this experiment are as followes: 2700 Multimeter/Data Acquisition system of Keithley Co., was used for collecting the data of temperature measurement, T-type thermocouples and K-type thermocouples are the temperature sensors for lower temperature and higher temperature testing, respectively, the model TRM-123 temperature and radiation instrument produced by Jinzhou was used for testing the solar radiation density, and the model RYQ1 automatic surface meteorological station was used for measuring the environmental temperature and air relatives humidity.
Temperature and solar radiation were measured at fiveminute intervals and could be accessed instantaneously on the computer.

\section{Results and Discussion}

5.1. The Variation of Solar Radiation and Ambient Temperature. During the experimental period, the weather was sunny and little cloudy. The solar radiation and ambient temperature variation was shown in Figure 6. The solar radiation value is about $20.1 \mathrm{MJ} \cdot \mathrm{m}^{-2}$. The maximum solar radiation density is about $800 \mathrm{~W} \cdot \mathrm{m}^{-2}$ at time 11:45 AM. The ambient temperatures were measured by T-type thermocouples in this experiment. The maximum and the minimum ambient temperature were about $33.8^{\circ} \mathrm{C}$ and $19.4^{\circ} \mathrm{C}$ respectively. The average ambient temperature was $25.9^{\circ} \mathrm{C}$.

5.2. The Adsorbent Bed Temperature Variation. The adsorbent bed temperature variation of solar cooling tube was shown in Figure 7. In the daytime, the adsorbent bed received solar energy and the adsorbent temperature rose up rapidly to $233^{\circ} \mathrm{C}$. This temperature met with desorption demand and the refrigerant water was desorbed from the 13X zeolite adsorbent bed. The steam released the latent heat during condensation and became liquid, before being stored in the evaporator due to gravity. Throughout the day, the solar cooling tube received solar radiation while the refrigerant water steam continued desorbing from the adsorbent bed until the solar radiation was too weak for desorption. At night, the adsorbent temperature dropped and began to adsorb the water steam. In the adsorption process, the adsorbent bed temperature cooled down to a minimum temperature of about $33^{\circ} \mathrm{C}$. The temperature difference between adsorbent bed and ambient temperature was about $14^{\circ} \mathrm{C}$.

5.3. Condensation Temperature Variation. The condensation temperatures of the solar cooling tube were tested at this experiment. Two temperature test points were set on the outside of the condenser. In the desorption process during daylight, the refrigerant water vapor, which desorbed from the adsorbent bed at high temperature, was condensed in the condenser. The variation of the condensation temperature of the solar cooling tube can be seen in Figure 8. The temperature of condenser varied from $31.6^{\circ} \mathrm{C}$ to about $40.5^{\circ} \mathrm{C}$. The maximum and average temperature difference between condenser and ambient temperature was about $13.8^{\circ} \mathrm{C}$ and $9.7^{\circ} \mathrm{C}$, respectively.

5.4. Evaporation Temperature Variation. Two temperature test points were set on the outside of the evaporator. In the adsorption process at nighttime, the adsorbent bed adsorbs the refrigerant gas and keeps the evaporator liquid water evaporating and supply cooling mass to the outside. The variation of the evaporator temperature of the solar cooling tube can be seen in Figure 9. The temperature of evaporator mainly varied from $15^{\circ} \mathrm{C}$ to about $10^{\circ} \mathrm{C}$ and the minimum evaporator temperature is about $9.2^{\circ} \mathrm{C}$. 


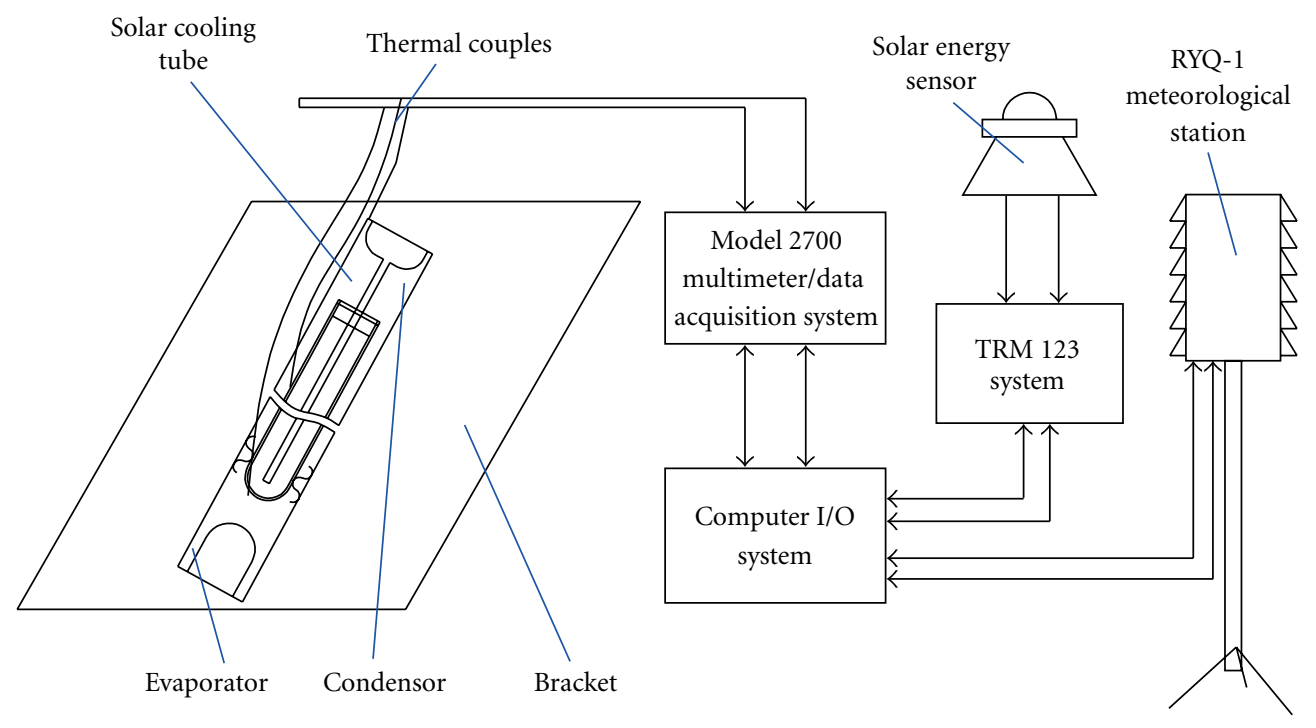

FIGURE 4: The experiment of solar cooling tube performance.

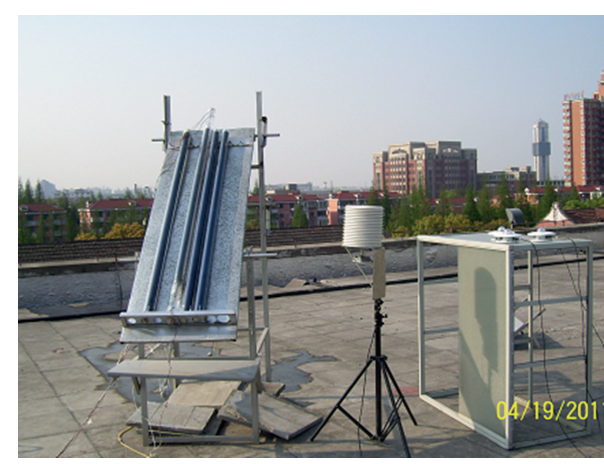

FIGURE 5: The photograph of the experiment.

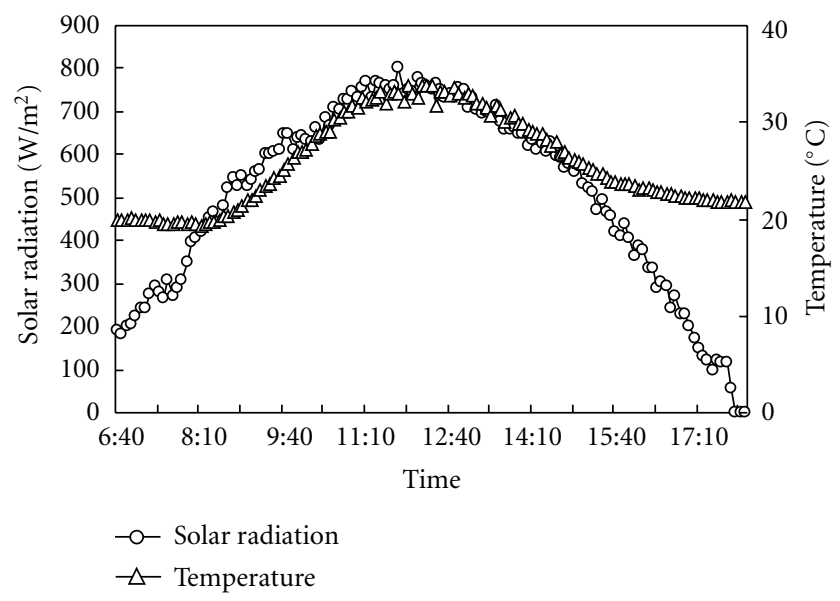

FIGURE 6: Solar radiation and ambient temperature variation.

5.5. Desorption Capacity Variation. The desorption capacity variation of the solar cooling tube can be seen in Figure 10. During the daytime, the adsorbent bed temperature rose as solar energy was received. The refrigerant water gas was

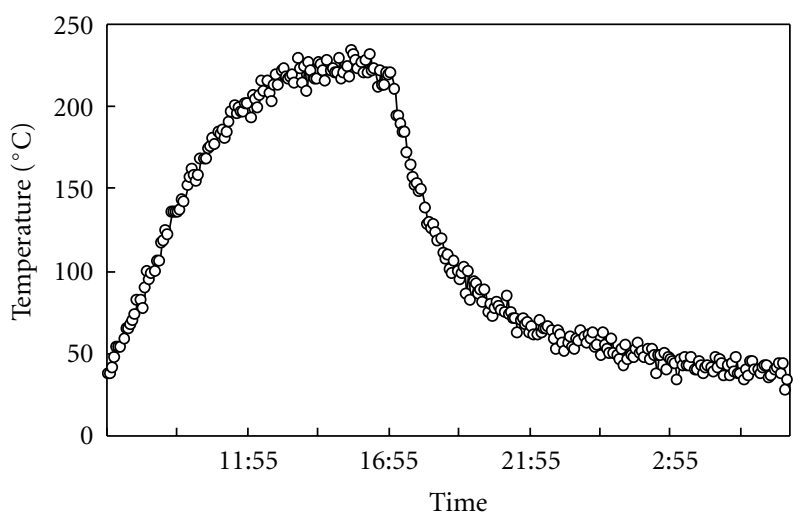

FIgURE 7: The adsorbent bed temperature variation of the solar cooling tube.

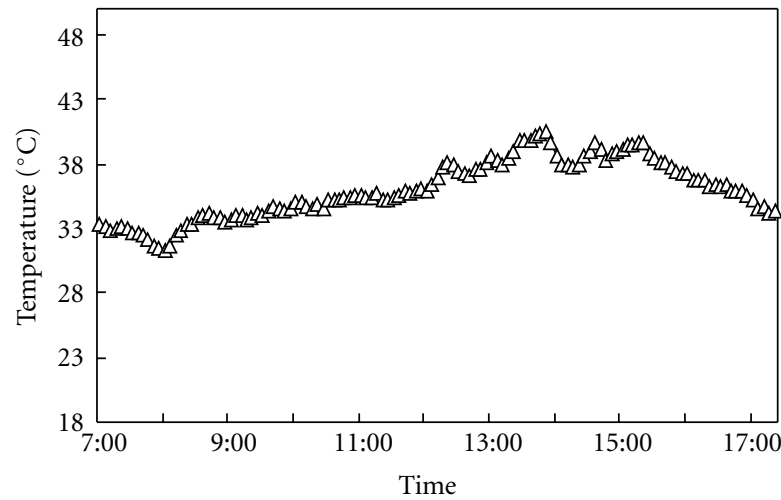

Figure 8: The condensation temperature variation.

desorbed from the adsorbent bed and stored in the evaporator. Desorption capacity was measured by the quantity of the refrigerant water. From 9:00 to 12:00, the speed of 


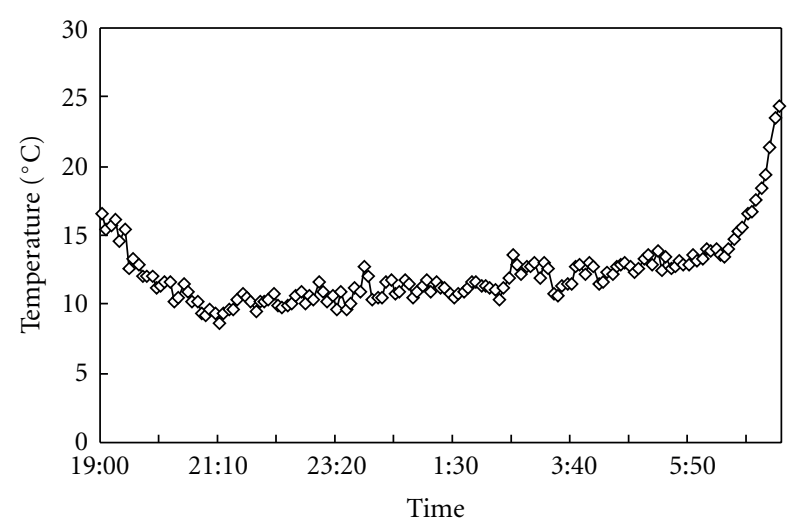

FIGURE 9: The evaporation temperature variation.

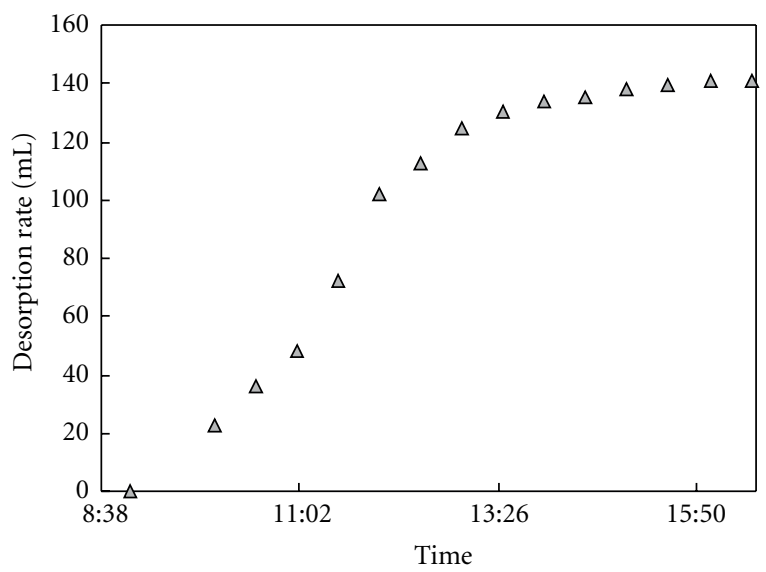

FIGURE 10: The desorption capacity variation of the solar cooling tube.

desorption was higher and was slow down after 13:00. The total desorption capacity was about $140 \mathrm{~g}$.

5.6. Evaporative Refrigeration Capacity of a Single Solar Cooling Tube. The refrigerator power variation of a single solar cooling tube can be seen in Figure 11. In the adsorption process at nighttime, the adsorbent bed adsorbed the refrigerant gas and keeps the evaporator liquid water evaporating supply cooling mass to the outside. The refrigerator power of a single solar cooling tube varied from $12 \mathrm{~W}$ at about $20: 00^{\circ} \mathrm{C}$ and weakened to less than $1 \mathrm{~W}$ by the following morning. The total supply refrigerating capacity was about $287 \mathrm{~kJ}$ and the COP of this solar cooling tube was about 0.215 .

\section{Conclusions}

This paper focused on an experimental study of a solar cooling tube using a thermal/vacuum emptying method. The solar cooling tube uses solar energy as a heating resource to complete the adsorption cycle, reducing damage to the environment compared to common alternatives. The performance of solar cooling tube was experimentally

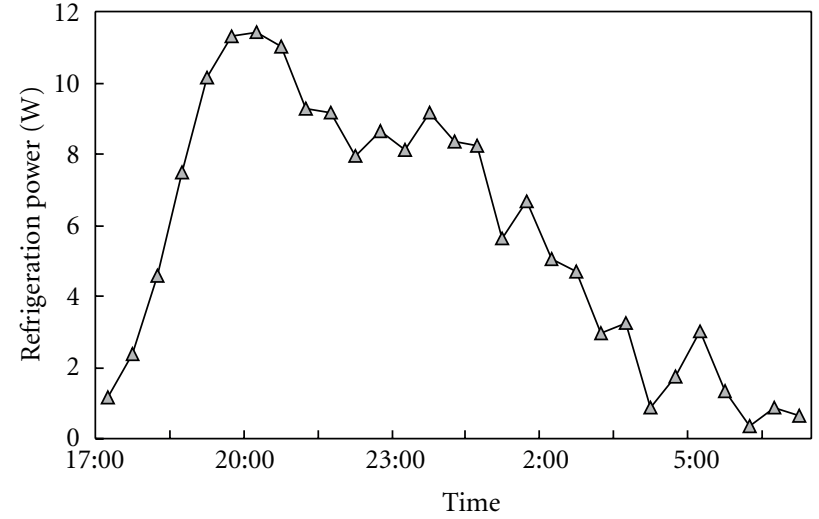

FIGURE 11: The refrigerator power of a single solar cooling tube.

studied in this research and the following conclusions can be drawn:

(1) When ambient temperature is about $19.4^{\circ} \mathrm{C}-33.8^{\circ} \mathrm{C}$, and the solar radiation is about $20.1 \mathrm{MJ} \cdot \mathrm{d}^{-1} \mathrm{~m}^{-2}$, the adsorbent bed temperature of solar cooling tube reaches up to $233^{\circ} \mathrm{C}$. This temperature canmeet desorption demand.

(2) At the nighttime, the adsorbent bed temperature of the solar cooling tube cooled down to the minimum temperature about $33^{\circ} \mathrm{C}$ and this temperature can meet adsorption demand. The temperature difference between adsorbent bed and ambient temperature is about $14^{\circ} \mathrm{C}$.

(3) The refrigerator power of a single solar cooling tube varied from $12 \mathrm{~W}$ to $1 \mathrm{~W}$. The total supply refrigerating capacity is about $287 \mathrm{~kJ}$ and the COP of this solar cooling tube is about 0.215 .

\section{Acknowledgments}

This work was supported by Natural Science Foundation of China (Contract no. 50976073) and Science and Technology Program of Shanghai Maritime University.

\section{References}

[1] A. P. Ferreira Leite, F. A. Belo, M. M. Martins, and D. B. Riffel, "Central air conditioning based on adsorption and solar energy," Applied Thermal Engineering, vol. 31, no. 1, pp. 50-58, 2011.

[2] N. M. Khattab, "A novel solar-powered adsorption refrigeration module," Applied Thermal Engineering, vol. 24, no. 17-18, pp. 2747-2760, 2004.

[3] L. W. Wang, R. Z. Wang, Z. S. Lu, Y. X. Xu, and J. Y. Wu, "Split heat pipe type compound adsorption ice making test unit for fishing boats," International Journal of Refrigeration, vol. 29, no. 3, pp. 456-468, 2006.

[4] L. W. Wang, R. Z. Wang, Z. S. Lu, and C. J. Chen, "Studies on split heat pipe type adsorption ice-making test unit for fishing boats: choice of heat pipe medium and experiments under unsteady heating sources," Energy Conversion and Management, vol. 47, no. 15-16, pp. 2081-2091, 2006. 
[5] M. Clausse, K. C. A. Alam, and F. Meunier, "Residential air conditioning and heating by means of enhanced solar collectors coupled to an adsorption system," Solar Energy, vol. 82, no. 10, pp. 885-892, 2008.

[6] E. E. Anyanwu and N. V. Ogueke, "Thermodynamic design procedure for solid adsorption solar refrigerator," Renewable Energy, vol. 30, no. 1, pp. 81-96, 2005.

[7] E. E. Anyanwu, U. U. Oteh, and N. V. Ogueke, "Simulation of a solid adsorption solar refrigerator using activated carbon/methanol adsorbent/refrigerant pair," Energy Conversion and Management, vol. 42, no. 7, pp. 899-915, 2001.

[8] N. M. Khattab, H. Sharawy, and M. Helmy, "Development of novel solar adsorption cooling tube," Energy Procedia, vol. 18, pp. 709-714, 2012.

[9] N. M. Khattab, "Simulation and optimization of a novel solarpowered adsorption refrigeration module," Solar Energy, vol. 80, no. 7, pp. 823-833, 2006.

[10] J. J. Guilleminot, A. Choisier, J. B. Chalfen, S. Nicolas, and J. L. Reymoney, "Heat transfer intensification in fixed bed adsorbers," Heat Recovery Systems and CHP, vol. 13, no. 4, pp. 297-300, 1993.

[11] A. Boubakri, J. J. Guilleminot, and F. Meunier, "Adsorptive solar powered ice maker: experiments and model," Solar Energy, vol. 69, no. 3, pp. 249-263, 2000.

[12] F. Bentayeb, F. Lemmini, and J. J. Guilleminot, "Adaptation of an adsorptive solar refrigerator to Moroccan climates," Renewable Energy, vol. 6, no. 7, pp. 867-882, 1995.

[13] Z. Liu, Y. Lu, and J. Zhao, "Zeolite-active carbon compound adsorbent and its use in adsorption solar cooling tube," Solar Energy Materials and Solar Cells, vol. 52, no. 1-2, pp. 45-53, 1998.

[14] H. Zhao, M. Zhang, L. Zhenyan, L. Yanling, and M. Xiaodong, "Mechanical and experimental study on freeze proof solar powered adsorption cooling tube using active carbon/methanol working pair," Energy Conversion and Management, vol. 49, no. 8, pp. 2434-2438, 2008.

[15] H. Zhao, M. Zhang, J. Lv, G. Yu, and Z. Zou, "Thermal conductivities study of new types of compound adsorbents used in solar adsorption refrigeration," Energy Conversion and Management, vol. 50, no. 5, pp. 1244-1248, 2009. 

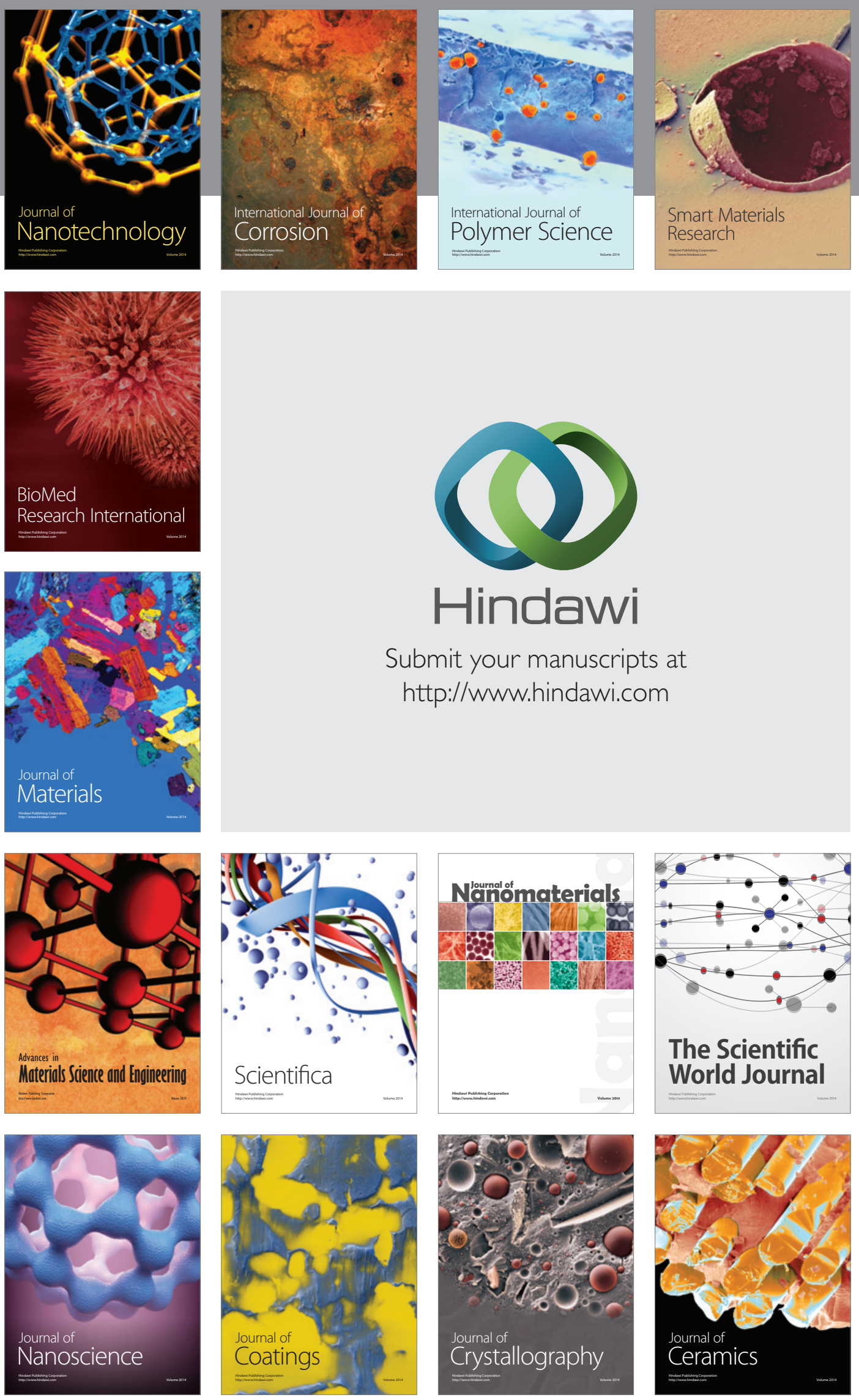

The Scientific World Journal

Submit your manuscripts at

http://www.hindawi.com

\section{World Journal}

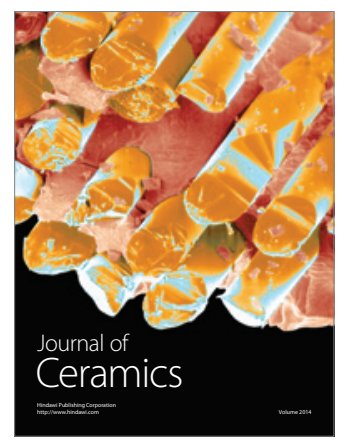

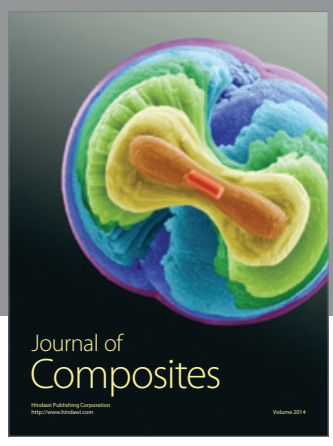
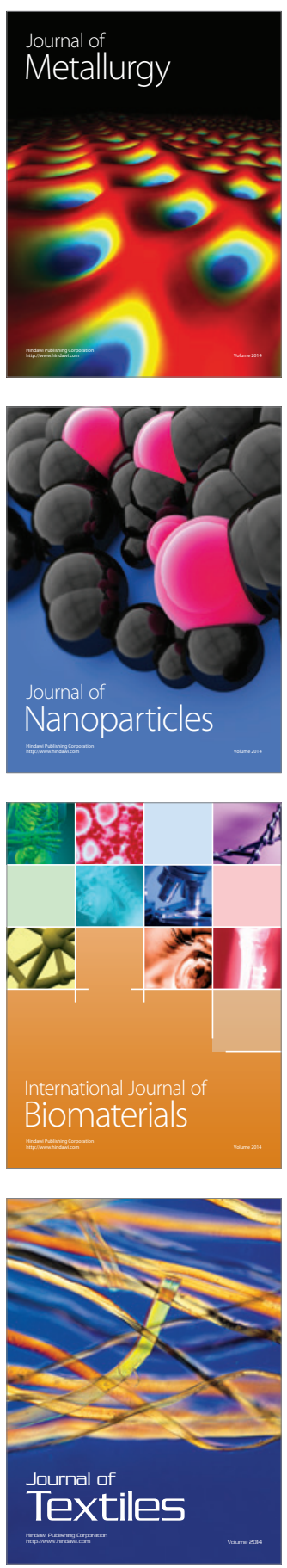